\title{
Pengaruh Luas Lahan, Curahan Tenaga Kerja Dan Biaya Sarana Produksi Terhadap Produksi Usaha Tani Kentang Di Desa Sempajaya, Kecamatan Berastagi,Kabupaten Karo
}

\author{
Fajar Rezeki Ananda Lubis ${ }^{*}$ \\ Syaifuddin $^{2}$ \\ Yusniar Lubis ${ }^{3}$ \\ ${ }^{1}$ Fakultas Ekonomi Universitas UNPRI, Medan \\ ${ }^{2}$ Dosen dpk. Universitas UNPRI, Medan \\ ${ }_{3}^{3}$ Magister Agribisnis Pascasarjana Universitas Medan Area, Medan \\ *email: fajarrezekiananda@gmail.com \\ Diterima: Desember 2020; Disetujui: September 2020; Dipublish: Oktober 2021
}

\begin{abstract}
Abstrak
Kentang merupakan komoditas yang berperan penting bagi masyarakat karena berperan sebagai pemenuhan kebutuhan pangan dan juga gizi masyarakat. Salah satu propinsi penghasil kentang di provinsi Sumatera Utara adalah Kabupaten Karo sehingga tujuan dari penelitian ini adalah untuk menganalisis faktor yang mempengaruhi produksi kentang, menganalisis layak atau tidaknya usaha tani kentang, dan mengetahui saluran pemasaran kentang di desa Sempajaya, Kecamatan Berastagi Kabupaten Karo. Adapun metode yang digunakan dalam penentuan sampel petani kentang adalah Stratified Random Sampling, yaitu strata luas lahan kecil $(\leq 0,5 \mathrm{ha})$ dan strata luas lahan besar $(>0,5 \mathrm{ha})$. Metode penentuan sampel pedagang kentang yang digunakan adalah snowball sampling dengan jumlah sebanyak 8 (delapan) orang. Metode analisis data dilakukan secara deskriptif dan regresi non linear berganda. Hasil penelitian menunjukkan secara simultan luas lahan, curahan tenaga kerja, dan biaya sarana produksi berpengaruh signifikan terhadap produksi usaha tani kentang. Secara parsial biaya sarana produksi berpengaruh signifikan terhadap produksi usahatani kentang. Pada daerah penelitian layak diperolehnya nilai R/C rasio sebesar 2,14 > 1, BEP produksi sebesar 6.082,14 $\mathrm{kg}<$ rata-rata produksi petani sampel sebesar $7.930 \mathrm{~kg}$, dan BEP harga sebesar Rp 2.583,73/kg $<$ rata-rata harga jual kentang sebesar Rp 5.500,-/kg. Selanjutnya, terdapat tiga saluran pemasaran kentang di daerah penelitian. Saluran pertama yaitu petani, pedagang besar, pedagang pengecer, konsumen di Medan. Saluran kedua yaitu petani, pedagang pengecer, konsumen di Medan. Saluran ketiga yaitu petani, pedagang pengumpul, pedagang pengecer di Berastagi.
\end{abstract}

Kata Kunci : Luas Lahan; Tenaga Kerja; Saluran; Kelayakan; Produksi

\begin{abstract}
Potato is a commodity that plays an important role for the community because it plays a role in meeting the food and nutritional needs of the community. One of the potato-producing provinces in North Sumatra is Karo Regency, so the purpose of this study is to analyze the factors that influence potato production, analyze whether or not potato farming is feasible, and determine the marketing channels for potatoes in Sempajaya Village, Berastagi Subdistrict, Karo Regency. The method used in determining the sample of potato farmers is Stratified Random Sampling, namely small land area strata (? $0.5 \mathrm{ha}$ ) and large land area strata ( $>0.5 \mathrm{ha}$ ). The method of determining the sample of potato traders used was snowball sampling with a total of 8 (eight) people. The data analysis method was carried out descriptively and multiple non-linear regression. The results showed that simultaneously the area of land, the amount of labor, and the cost of production facilities had a significant effect on the production of potato farming. Partially the
\end{abstract}


cost of production facilities has a significant effect on potato farming production. In the research area, it is feasible to obtain an $R / C$ ratio of 2.14> 1, BEP for production of 6,082.14 $\mathrm{kg}<$ average production of sample farmers is 7,930 kg, and BEP price of IDR 2,583.73 / kg <average price selling potatoes for IDR 5,500 / kg. Furthermore, there are three marketing channels for potatoes in the study area. The first channel is farmers, wholesalers, retailers, consumers in Medan. The second channel is farmers, retailers, consumers in Medan. The third channel is farmers, collectors, and retailers in Berastagi.

Keywords : Land Area; Labor; Channels; Feasibility; Production

\section{PENDAHULUAN}

Indonesia dikenal sebagai negara yang mengandalkan sektor pertanian sebagai penopang pembangunan dan juga sebagai sumber mata pencaharian penduduknya. Sektor pertanian di Indonesia meliputi sub sektor tanaman pangan, sub sektor hortikultura, sub sektor perikanan, sub sektor peternakan, dan sub sektor kehutanan. Pada tahap awal pembangunan, sektor pertanian merupakan penopang perekonomian. Hal ini dikarenakan pertanian membentuk proporsi yang sangat besar bagi devisa negara, penyedia lapangan pekerjaan, dan sumber pendapatan masyarakat (Khazanani, 2011).

Salah satu dari sub sektor pertanian di Indonesia yang sedang semarak dikembangkan adalah sub sektor hortikultura. Hortikultura merupakan salah satu sub sektor penting dalam pembangunan pertanian. Secara garis besar, komoditas hortikultura terdiri dari kelompok tanaman sayuran (vegetables), buah (fruits), tanaman berkhasiat obat (medicinal plants), tanaman hias (ornamental plants), termasuk di dalamnya tanaman air, lumut, dan jamur yang dapat berfungsi sebagai sayuran, tanaman obat atau tanaman hias (Dirjen Hortikultura, 2014).

Direktorat Jendral Hortikultura (2018), telah ditetapkan empat komoditas unggulan provinsi Sumatera Utara yaitu komoditas kentang, jeruk, kubis, dan tanaman hias. Indonesia masih tertinggal dalam produktivitas kentang hanya 16,58 ton/hektar apabila dibandingkan dengan negara di luar Indonesia misalnya China dan India merupakan negara utama penghasil kentang di Asia, disusul oleh Bangladesh, Korea Utara, Nepal, Pakistan, Vietnam, dan Korea Selatan. Selanjutnya untuk Asia kondisi terakhir, seperti Korea Selatan dan China merupakan negara dengan produksi tertinggi mencapai sekitar 30 - 35 hektar. Kondisi tersebut masih jauh dibandingkan dengan Belanda yang mencapai 70 - 80 ton/hektar, Amerika 80 - 90/hektar dan Australia kemungkinan tertinggi mencapai di atas 100 ton/ha.

Kentang merupakan komoditas yang berperan penting bagi masyarakat karena berperan sebagai pemenuhan kebutuhan pangan dan juga gizi masyarakat. Sayuran merupakan komoditas yang memiliki kontribusi penting dalam sub sektor Hortikultura. Kabupaten Karo merupakan salah satu 
propinsi penghasil kentang di provinsi Sumatera Utara.

Berdasarkan tabel di atas dapat dilihat bahwa Kabupaten Karo merupakan daerah sentra produksi kentang urutan terbesar di Provinsi Sumatera Utara dengan luas panen sebesar 3.953 ha dan produksi 723.080 ton di ikutin oleh kabupaten simalungun dengan luas lahan $1.740 \mathrm{Ha}$ dengan produksi 286.913 Ton selanjutnya pada urutan ketiga adalah samosir dengan luas lahan $462 \mathrm{Ha}$ dengan produksi 93.140 Ton. Dari ketiga tersebut dapat kita lihat kabupaten samosir dengan luas lahan dan produksi terkecil dari kedua kabupaten lainnya tetapi memiliki produktivitas tertinggi yaitu 201 Ton berbeda dengan kabupaten Karo dnegan Luas lahan terbesar dan produksi yang besar tetapi memliki produktivitas yang lebih rendah dibandingkan kabupaten Samosir. Sebagai sentra penghasil kentang di Sumatera Utara, Kabupaten Karo harus dapat lebih diperhatikan.

Kabupaten Karo adalah salah satu sentra penghasil kentang di Provinsi Sumatera Utara, lahan pertanaman kentang di Kabupaten Karo tersebar di beberapa kecamatan. Pada tahun 2019, Kecamatan Berastagi merupakan salah satu sentra produksi kentang di Kabupaten Karo. Produksi kentang yang tinggi memerlukan penanganan pasca panen yang baik sehingga kentang tidak mudah mengalami penurunan kualitas sebelum dipasarkan ke daerah konsumen.
Menurut Minsyah (2009) rendahnya produksi kentang di kabupaten Karo antara lain disebabkan oleh mutu bibit, pemupukan, penggunaan pestisida, kontinuitas pasokan, dan upaya efisiensi biaya produksi kentang. Disamping itu produksi kentang juga dipengaruhi oleh fluktuatifnya luas areal panen komoditas kentang antara lain disebabkan oleh beberapa faktor. Pertama, meningkatnya harga input baik benih, pupuk serta pestisida dan fungisida. Kedua, adanya fasilitas bantuan sarana produksi dari pemerintah. Ketiga, serangan hama dan penyakit terutama penyakit busuk daun, penyakit bercak kuning dan penyakit layu fusarium, dan hama Trips. Dalam hal ini tidak semua kentang yang ditanam dapat di panen karena terjadinya serangan hama dan penyakit akibatnya gagal panen. Keempat, adanya komoditas pesaing yaitu komoditas yang harganya lebih mahal pada saat-saat tertentu seperti bawang merah, wortel dan lain-lain. Sistem tanam dan pola tanam tidak hanya didasarkan pertimbangan teknis produksi namun juga telah didasarkan ekspektasi akan harga komoditas apa yang paling menguntungkan. Kelima, pola tanam dan pola curah hujan di daerah produsen. Keenam, fluktuasi harga jual kentang.

Berdasarkan kondisi produksi kentang yang masih rendah, maka penulis tertarik untuk melakukan penelitian yang bertujuan untuk mengetahui faktor-faktor apa saja yang 
mempengaruhi produksi kentang, layak atau tidaknya kentang untuk dibudidayakan, dan saluran pemasaran kentang di daerah penelitian. Adapun tujuan dari penelitian ini yang menjadi keterbaharuan dalam penelitian ini yaitu untuk mengetahui faktor-faktor yang mempengaruhi produksi kentang di daerah penelitian, mengetahui layak atau tidaknya usahatani kentang di daerah penelitian, dan mengetahui saluran pemasaran kentang di daerah penelitian.

Tabel 1. Luas Panen dan Produksi Tanaman Kentang di Kecamatan Berastagi

\begin{tabular}{|c|c|c|c|}
\hline No & Desa & $\begin{array}{c}\text { Luas panen } \\
\text { (Ha) }\end{array}$ & $\begin{array}{c}\text { Produksi } \\
\text { (Ton) }\end{array}$ \\
\hline 1 & Doulu & 14 & 172 \\
\hline 2 & Gundaling I & 15 & 202 \\
\hline 3 & Gundaling II & 19 & 252 \\
\hline 4 & Gurusinga & 17 & 241 \\
\hline 5 & Raya & 15 & 227 \\
\hline 6 & RH Berastagi & 23 & 344 \\
\hline 7 & Sempajaya & 15 & 261 \\
\hline 8 & Tambak Lau Mulgap I & 10 & 176 \\
\hline 9 & Tambak Lau Mulgap II & 16 & 219 \\
\hline \multirow[t]{2}{*}{10} & Lau Gamba & 10 & 134 \\
\hline & Total & 154 & 2228 \\
\hline
\end{tabular}

Sumber: BP3K Kecamatan Berastagi (2019)

Populasi dalam penelitian ini adalah seluruh petani kentang dan pedagang kentang yang ada di daerah penelitian. Dimana jumlah populasi petani kentang yang ada di desa Sempajaya, Kecamatan Berastagi, Kabupaten Karo sebanyak 57 orang dengan luas lahan yang bervariasi. Oleh karena itu, metode yang digunakan dalam penentuan petani sampel penelitian adalah Stratified Random Sampling, yaitu dengan mengelompokkan sampel ke dalam

\section{METODE PENELITIAN}

Daerah penelitian ditentukan secara purposive, yaitu di desa Sempajaya kecamatan Berastagi kabupaten Karo. Adapun pertimbangan objektif penulis dalam menentukan desa tersebut sebagai daerah penelitian adalah karena desa Sempajaya merupakan daerah penghasil kentang terbesar di kecamatan Berastagi, kabupaten Karo seperti terlihat pada Tabel 1 berikut. 
Tabel 2 Distribusi Populasi dan Sampel Petani Kentang berdasarkan Luas Lahan di Desa Sempajaya Kecamatan Berastagi Tahun 2019

\begin{tabular}{cccc}
\hline Strata & $\begin{array}{c}\text { Luas } \\
\text { Lahan } \\
\text { (Ha) }\end{array}$ & $\begin{array}{c}\text { Populasi } \\
\text { (org) }\end{array}$ & $\begin{array}{c}\text { Sampel } \\
\text { (org) }\end{array}$ \\
\hline I & $\leq 0,5$ & 21 & 11 \\
II & $>0,5$ & 36 & 19 \\
\hline Jumlah & & 57 & 30 \\
\hline
\end{tabular}

Sumber : Kantor Kepala Desa (2019)

Selanjutnya, metode penentuan sampel pedagang kentang yang digunakan adalah snowball sampling yang artinya dilakukan penelusuran sampel dari jumlah sedikit lama kelamaan menjadi banyak. Hal ini dikarenakan keterbatasan data tentang populasi pedagang yang ada di daerah penelitian.

Data yang dikumpulkan dalam penelitian terdiri dari data primer dan data sekunder. Data primer diperoleh dari hasil wawancara langsung terhadap petani dan pedagang kentang dengan menggunakan alat bantu berupa kuesioner. Data sekunder diperoleh dari studi kepustakaan baik berupa buku, jurnal maupun data statistik dari instansi terkait yang berhubungan dengan penelitian ini.

Untuk pengujian tujuan penelitian (1) digunakan Analisis Regresi Non Linear Berganda, sebagai berikut:

$$
\mathrm{Y}=\mathrm{b}_{0} \mathrm{X}_{1} \mathrm{~b}^{1} \mathrm{X}_{2} \mathrm{~b}^{2} \mathrm{X}_{3}{ }^{\mathrm{b} 3}
$$

Model di atas diselesaikan dalam bentuk linear dengan model logaritma sebagai berikut :

$\log Y=\log b_{0}+b_{1} \log X_{1}+b_{2} \log X_{2}+$ $\mathrm{b}_{3} \log \mathrm{X}_{3}+\varepsilon$
Dimana:

Y : Produksi usahatani kentang $(\mathrm{kg})$

$\mathrm{b}_{0} \quad$ : Intercept/konstanta

$\mathrm{X}_{1} \quad$ : Luas lahan (ha)

$\mathrm{X}_{2} \quad$ : Curahan tenaga kerja (HKP)

$\mathrm{X}_{3} \quad$ : Biaya sarana produksi (Rp)

$\mathrm{b}_{1}, \mathrm{~b}_{2}, \mathrm{~b}_{3}$ : Koefisien regresi

$\varepsilon \quad:$ Error/koefisien pengganggu

Untuk analisis kelayakan dengan $\mathrm{R} / \mathrm{C}$ rasio, BEP produksi dan BEP harga yang dirumuskan sebagai berikut (Soekartawi, 2006):

1. R/C Rasio

$$
\mathrm{R} / \mathrm{C} \text { rasio }=\frac{\text { Penerimaan }}{\text { Total Biaya Produksi }}
$$

Kriteria Pengujian :

Apabila $\mathrm{R} / \mathrm{C}$ rasio $<1$, maka usahatani dikatakan tidak layak.

Apabila $\mathrm{R} / \mathrm{C}$ rasio $=1$, maka usahatani berada pada titik balik modal.

Apabila $\mathrm{R} / \mathrm{C}$ rasio $>1$, maka usahatani dikatakan layak.

2. BEP Produksi

BEP produksi $(\mathrm{kg})=\frac{\text { Total Biaya Produksi }}{\text { Harga Jual }}$

3. BEP Harga

BEP harga $(\mathrm{kg})=\frac{\text { Total Biaya Produksi }}{\text { Total Produksi }}$

Untuk melakukan penelurusan saluran pemasaran kentang mulai dari petani hingga konsumen di daerah penelitian dilakukan dengan deskriftif.

\section{HASIL DAN PEMBAHASAN}

Untuk menganalisis faktor yang berpengaruh terhadap produksi usahatani kentang, dianalisis dengan Fungsi Produksi Cobb-Douglas yang dilogaritmakan. 
Tabel 3. Analisis Pengaruh Luas Lahan, Curahan Tenaga Kerja dan Biaya Sarana Produksi terhadap Produksi Usahatani Kentang

\begin{tabular}{lllll}
\hline Variabel Bebas & $\begin{array}{l}\text { Koefisien } \\
\text { Regresi }\end{array}$ & $\begin{array}{l}\text { Std. } \\
\text { Error }\end{array}$ & t-hitung & Signifikan \\
\hline Konstanta & $-0,401$ & 0,938 & $-0,428$ & 0,672 \\
$\mathrm{X}_{1}=$ Luas Lahan & 0,180 & 0,118 & 1,518 & 0,141 \\
$\mathrm{X}_{2}=$ Curahan Tenaga Kerja & 0,211 & 0,214 & 0,985 & 0,334 \\
$\mathrm{X}_{3}=$ Biaya Sarana Produksi & 0,538 & 0,157 & 3,434 & 0,002 \\
$\mathrm{R} \quad=0,986$ & & & & \\
$\mathrm{R}^{2} \quad=0,973$ & & & & \\
F-hitung $=309,758$ & & & & \\
Sig. F $=0,000$ & & & & \\
F-tabel $=2,98$ & & & \\
t-tabel $=1,699$ & & &
\end{tabular}

Keterangan :

F-tabel $=2,98$

th = tidak nyata

Berdasarkan hasil analisis fungsi produksi Cobb-Douglass diperoleh persamaan regresi sebagai berikut :

$$
\begin{aligned}
\mathrm{Y}= & -0,401+0,180 \mathrm{X}_{1}+ \\
& 0,211 \mathrm{X}_{2}+0,538 \mathrm{X}_{3} ; \\
\mathrm{t}-\text { hit }= & \begin{array}{c}
(-0,428) \quad(1,518) \\
(0,985) \quad(3,343)
\end{array}
\end{aligned}
$$

Deskripsi dari persamaan model regresi linear di atas adalah sebagai berikut :

$b_{0}$ : $-0,401$; Bilangan konstanta $\left(b_{0}\right)$ sebesar -0,401 menunjukkan besarnya produksi usahatani kentang apabila luas lahan, curahan tenaga kerja dan biaya sarana produksi sama dengan nol.

$b_{1}: 0,180$; Koefisien regresi pertama $\left(b_{1}\right)$ sebesar 0,180 menunjukkan besarnya pengaruh luas lahan terhadap produksi usahatani kentang dengan asumsi curahan tenaga kerja dan biaya sarana produksi konstan.

$b_{2}$ : 0,211; Koefisien regresi kedua (b2) sebesar 0,211 menunjukkan besarnya pengaruh curahan tenaga kerja terhadap produksi usahatani kentang dengan asumsi luas lahan dan nilai sarana produksi usahatani konstan.

b3 $_{3}$ : 0,538; Koefisien regresi ketiga (b3) sebesar 0,538 menunjukkan besarnya pengaruh nilai sarana produksi usahatani terhadap produksi usahatani kentang dengan asumsi luas lahan dan curahan tenaga kerja konstan.

Nilai koefisien determinasi $\left(R^{2}\right)$ sebesar 0,973 menunjukkan bahwa sekitar 97,30 \% variasi variabel terikat/dependent variable (produksi usahatani kentang) dapat dijelaskan variasi variabel bebas/independent varible (luas lahan, curahan tenaga kerja dan biaya sarana produksi) yang terdapat dalam persamaan, sedangkan sisanya yaitu $2,70 \%$ tidak dapat dijelaskan oleh variasi variabel terikat, tetapi dapat dijelaskan oleh variabel bebas lain di luar persamaan. 
Pengaruh variabel bebas (luas lahan, curahan tenaga kerja dan biaya sarana produksi) secara serempak diuji dengan analisis $F_{\text {hitung. Dari hasil }}$ analisis Cobb-Douglas seperti pada Tabel 5 diketahui bahwa Fhitung sebesar 309,758. Hal ini menunjukkan bahwa Fhitung $(309,758)>F_{\text {tabel }}(2,98)$ dan signifikansi F $(0,000) \leq \alpha(0,05)$, artinya bahwa variabel-variabel bebas (luas lahan, curahan tenaga kerja, dan sarana produksi) yang terdapat dalam persamaan secara serempak berpengaruh nyata terhadap variabel terikat (produksi) pada tingkat kepercayaan $5 \%$.

Pemanfaatan lahan dalam usahatani kentang akan semakin meningkatkan produksi umbi. Penggunaan lahan yang semakin luas membutuhkan tenaga kerja dan sarana produksi yang semakin meningkat. Tersedianya tenaga kerja maka dapat menjamin proses pengerjaan setiap jenis kegiatan usahatani dapat berlangsung dengan baik. Tersedianya sarana produksi maka pemberian sarana produksi sesuai dengan dosis anjuran akan semakin meningkatkan pertumbuhan tanaman kentang, karena pemberian sarana produksi dapat menyediakan pasokan unsur hara nitrogen yang sangat dibutuhkan dalam pertumbuhan dan pembentukan umbi kentang. Perawatan tanaman kentang dari serangan hama dan penyakit dapat meningkatkan produksi tanaman kentang menjadi maksimal. Pengendalian serangan hama dan penyakit pada tanaman kentang dilakukan dengan penyemprotan pestisida secara berkala.

\section{a. Luas Lahan $\left(\mathrm{X}_{1}\right)$ terhadap Produksi Usahatani Kentang}

Pengaruh luas lahan terhadap produksi usahatani kentang dapat dilihat dari nilai thitung luas lahan. Nilai thitung $\left(1,518<t_{\text {tabel }}(1,699)\right.$ dan signifikansi t $(0,141)>\alpha(0,05)$, maka secara parsial luas lahan tidak berpengaruh signifikan terhadap produksi kentang. Hal ini disebabkan walaupun terjadi peningkatan luas lahan, tetapi tidak disertai penyediaan sarana produksi yang optimal, maka produksi umbi kentang yang dihasilkan tidak mengalami perubahan signifikan. Dengan kata lain, peningkatan luas lahan tidak menjamin peningkatan produksi umbi kentang yang dihasilkan.

\section{b. Curahan Tenaga Kerja (X $\left.\mathrm{X}_{2}\right)$ terhadap Produksi Usahatani Kentang}

Berdasarkan Tabel 5 diperoleh nilai thitung $\left(0,985<t_{\text {tabel }}(1,699)\right.$ dan signifikansi t $(0,344>\alpha(0,05)$, maka secara parsial curahan tenaga kerja tidak berpengaruh signifikan terhadap produksi kentang. Hal ini dikarenakan penggunaan tenaga kerja yang lebih banyak dapat mempercepat proses pekerjaan, tetapi belum tentu dapat meningkatkan produksi kentang. Fianda et al., (2016), dalam penelitiannya juga menunjukkan bahwa tenaga kerja tidak berpengaruh signifikan terhadap produksi kentang. Begitupula penelitian yang dilakukan oleh Agatha dan Wulandari (2018), menunjukkan bahwa tenaga kerja 
tidak berpengaruh signifikan terhadap produksi kentang

\section{c. Biaya Sarana Produksi $\left(\mathrm{X}_{3}\right)$ terhadap Produksi Usahatani Kentang}

Nilai thitung $\left(3,434>t_{\text {tabel }}(1,699)\right.$ dan signifikansi t $(0,002) \leq \alpha(0,05)$, maka secara parsial biaya sarana produksi berpengaruh signifikan terhadap produksi kentang. Dimana apabila terjadi panambahan biaya sarana produksi sebesar Rp. 1,-, maka produksi kentang akan bertambah juga sebesar 0,538 kg dan sebaliknya. Tersedianya biaya sarana produksi dapat memenuhi kebutuhan benih, pupuk dan pestisida, sehingga dapat menjamin berlangsungnya proses usahatani kentang. Penggunaan bibit unggul kentang dapat meningkatkan produksi yang dihasilkan, dimana setiap varietas kentang memiliki ketahanan terhadap beberapa penyakit tertentu, dimana tanaman kentang sangat rentan terhadap perubahan iklim dan serangan hama dan penyakit. Pemberian pupuk dan pestisida dapat meningkatkan produksi tanaman, karena unsur hara sangat dibutuhkan dalam pembentukan umbi kentang. Penggunaan pestisida dapat mencegah tanaman dari serangan hama dan penyakit, sehingga produksi yang dihasilkan menjadi lebih tinggi.

Berdasarkan hasil uji parsial dari regresi non linear berganda diketahui bahwa hanya variabel bebas biaya sarana produksi yang berpengaruh signifikan terhadap produksi kentang di daerah penelitian. Biaya sarana produksi meliputi biaya bibit, pupuk, dan pestisida. Banyak penelitian yang menunjukkan hasil bahwa penggunaan bibit, pupuk, dan pestisida berpengaruh signifikan terhadap produksi kentang. Penelitian yang dilakukan oleh Rulianto et al. (2019), menunjukkan bahwa jumlah bibit, luas lahan, tenaga kerja, pupuk kandang dan pestisida sipermetrin berpangruh siginifikan terhadap faktor produksi usahatani kentang. Penelitian yang dilakukan oleh (Sa'diyah dan Muljawan, 2011) menunjukkan bibit merupakan faktor yang berpengaruh signifikan terhadap produksi kentang. Namun penggunaan bibit juga harus memperhatikan dengan anjuran penggunaan bibit. Rizkiyah et al., (2014); Ri Esso dan Ernawati(2018), dalam penelitiannya menunjukkan bahwa penambahan penggunaan bibit akan menurunkan produksi. Kondisi tersebut disebabkan karena petani tidak menggunakan bibit sesuai dengan anjuran Balai Pengkajian dan Pengembangan Teknologi yaitu $1,500-2,000 \mathrm{~kg} / \mathrm{ha}$. Hal tersebut menunjukkan bahwa sarana produksi sangat berpengaruh terhadap produksi kentang karena merupakan input yang penting bagi produksi kentang. Menurut, Sartika et al. (2013), faktor yang paling dominan yang berpengaruh terhadap produksi kentang adalah cara pemeliharaan kentang (31,22\%), kemudian permodalan dan lahan $(14,77 \%)$, dan faktor Pemupukan (11,42\%). 


\section{Kelayakan Usahatani Kentang}

\section{a. Total Biaya Produksi}

Total biaya produksi usahatani adalah penjumlahan dari biaya sarana produksi, biaya tenaga kerja dan biaya penyusutan peralatan yang terlihat dalam proses produksi usahatani kentang selama satu musim tanam. Rata-rata biaya produksi dalam usahatani kentang dapat dilihat pada Tabel 4.

Tabel 4. Rata-rata Total Biaya Produksi Usahatani Kentang di Daerah Penelitian

\begin{tabular}{llll}
\hline \multirow{2}{*}{ No } & \multicolumn{1}{c}{ Jenis Biaya } & \multicolumn{2}{c}{ Biaya (Rp) } \\
\cline { 3 - 4 } & \multicolumn{1}{c}{ Per Petani } & \multicolumn{1}{c}{ Per Hektar } \\
\hline 1 & Tenaga Kerja & $2.572 .266,67$ & $4.455 .710,65$ \\
2 & Sarana Produksi & $17.887 .166,67$ & $28.748 .531,25$ \\
3 & Penyusutan Peralatan & $117.035,33$ & $197.519,04$ \\
4 & Pajak & $31.333,33$ & $50.000,00$ \\
\hline \multicolumn{2}{c}{ Jumlah } & $20.607 .842,00$ & $33.451 .760,94$ \\
\hline
\end{tabular}

Berdasarkan Tabel 6 dapat diketahui bahwa total biaya usahatani kentang pada musim tanam II di daerah penelitian sebesar Rp 20.607.842,00/petani atau Rp. 33.451.760,94/ha. Jumlah biaya terbesar usahatani kentang terdapat pada biaya sarana produksi yaitu sebesar 85,94 \% dari total biaya produksi dalam usahatani kentang, diikuti oleh biaya tenaga kerja sebesar $13,32 \%$. Sedangkan biaya lain memiliki persentase yang relatif kecil seperti biaya penyusutan peralatan dan pajak.

\section{b. Produksi, Penerimaan, dan Pendapatan Usahatani Kentang}

Penerimaan dan pendapatan usahatani kentang merupakan ukuran yang sering dipergunakan untuk melihat keberhasilan atau kegagalan pengelolaan usahatani. Pendapatan bersih usahatani kentang adalah nilai produksi dikurangi dengan total biaya produksi, sementara pendapatan keluarga usahatani adalah nilai tenaga kerja dalam keluarga tidak diperhitungkan sebagai biaya produksi. Rata-rata pendapatan usahatani kentang tertera pada Tabel 5

Tabel 5. Rata-rata Pendapatan Usahatani Kentang di Daerah Penelitian

\begin{tabular}{llll}
\hline No & Uraian & Per Petani & Per Hektar \\
\hline 1 & Produksi & $7.930,00$ & $12.988,56$ \\
2 & Harga & $5.500,00$ & $5.500,00$ \\
3 & Penerimaan & $43.615 .000,00$ & $71.437 .106,48$ \\
4 & Biaya Produksi & $20.607 .842,00$ & $33.451 .760,94$ \\
5 & Pendapatan Bersih & $23.007 .158,00$ & $37.985 .345,54$ \\
\hline
\end{tabular}

Berdasarkan Tabel 5 dapat diketahui bahwa rata-rata penerimaan usahatani kentang adalah sebesar $\mathrm{Rp}$ 43.615.000,00/petani atau $\mathrm{Rp}$ 71.437.106,48/ ha, dengan rata-rata biaya produksi sebesar Rp. 20.607.842,00/petani atau Rp. 33.451.760,94/ha, sehingga diperoleh rata-rata pendapatan bersih usahatani kentang sebesar Rp 23.007.158,00/petani dan Rp $37.985 .345,54 /$ ha. Kusuma et al. 
(2015), menghitung pendapatan usahatani kentang per hektar di Kabupaten Merangin yaitu Rp. 24.521.148 per hektar. Kiloes et al. (2016), juga melakukan perhitungan usaha produksi kentang. Hasil perhitungannya menunjukkan bahwa harga kentang rerata pada harga privat sebesar Rp4.271,72/kg sedangkan harga kentang pada harga sosial sebesar Rp3.369,03/kg. Pada penelitian tersebut kentang dipetani antara Rp3.500,00-4.800,00/kg. Harga tersebut dirasakan belum layak bagi para petani dimana harga kentang yang dikehendaki untuk lebih memperbesar keuntungan berkisar antara Rp5.000,00- Rp6.000,00/kg. Berdasarkan penelitian ini, harga kentang di tingkat petani sebesar Rp5.500. Selain itu pada penelitian yang dilakukan oleh Kiloes et al. (2016) menunjukkan keuntungan petani sebesar Rp18.010.581,00.

Dari penelitian yang dilakukan oleh Kusuma et al. (2015); Kiloes et al.
(2016); Rahmah dan Wulandari (2021) menunjukkan bahwa hasil ekonomi petani pada penelitian ini berada di atas rata-rata. Menurut Budiwan et al. (2014), faktor-faktor yang berpengaruh pendapatan petani pada usahatani kentang di Kabupaten Karo adalah biaya pestisida dan biaya lahan. Faktor lainnya yang dapat berpengaruh yaitu jumlah produksi, dan harga jual kentang (Rahmah dan Wulandari, 2021).

\section{c. Kelayakan Usahatani Kentang}

Kelayakan usahatani kentang menggambarkan apakah usahatani kentang secara ekonomi menguntungkan atau tidak. Usahatani kentang akan mengalami keberlanjutan apabila dari aspek ekonomi menguntungkan bagi petani (Saida et al., 2011). Kelayakan usahatani kentang di daerah penelitian diukur dengan perhitungan Return cost $(R / C)$ ratio, BEP Harga dan BEP Produksi dapat dilihat pada Tabel 6 .

Tabel 6. Kelayakan Usahatani Kentang per Petani di Daerah Penelitian

\begin{tabular}{lll}
\hline No & \multicolumn{1}{c}{ Uraian } & \multicolumn{1}{c}{ Jumlah } \\
\hline 1 & Penerimaan (Rp/petani) & $43.615 .000,00$ \\
2 & Biaya Produksi (Rp/petani) & $20.607 .842,00$ \\
3 & Total Produksi (kg/petani) & $7.930,00$ \\
4 & Harga (Rp) & $5.500,00$ \\
5 & R/C & 2,14 \\
6 & BEP Produksi & $6.082,14$ \\
7 & BEP Harga & $2.583,73$ \\
\hline
\end{tabular}

Berdasarkan Tabel 6 dapat diketahui bahwa usahatani kentang masih layak untuk diusahakan oleh petani di daerah penelitian R/C $(2,14)$ $>1$ yang berarti usahatani kentang memberikan keuntungan secara ekonomi. Nilai $\mathrm{R} / \mathrm{C}=2,14$ menggambarkan bahwa dapat mengeluarkan biaya sebesar $\mathrm{Rp} 1$, maka petani akan memperoleh penerimaan sebesar Rp 2,14 sehingga diperoleh pendapatan bersih sebesar 
Rp 1,14. Hal ini menunjukkan bahwa usahatani kentang masih layak diusahakan atau dikembangkan di daerah penelitian karena memberikan keuntungan secara ekonomi. Penelitian yang dilakukan oleh Pratiwi dan Hardyastuti (2018); Kiloes et al. (2016); Budiwan et al. (2014), menunjukkan bahwa secara rata-rata usatani kentang layak untuk dilakukan. Namun, terdapat petani yang hasil usahatani kentangnya tidak layak untuk diusahakan karena penerimaan usahatani kentang hanya dapat menutup separuh biaya usahataninya. Disisi lain terdapat petani yang usahataninya sangat menguntungkan karena penerimaan yang diperoleh dari dapat menutup biaya usahataniya sebesar tiga kali lipat (Pratiwi dan Hardyastuti, 2018).

Berdasarkan Tabel 6 juga dapat dikatakan dengan produksi 7.930,00 ton/petani diperoleh Break Even Point (BEP) harga sebesar Rp 2.583,73/kg kentang < rata-rata harga jual kentang di daerah penelitian (Rp 5.500,-/kg), dan BEP produksi sebesar 6.082,14 kg < rata-rata produksi kentang di daerah penelitian sebesar $7.930 \mathrm{~kg}$, sehingga disimpulkan bahwa usahatani kentang layak diusahakan.

\section{Saluran Pemasaran Kentang di Daerah Penelitian}

Secara umum di daerah penelitian, petani produsen kentang modal, waktu, alat transportasi tidak langsung menjual sendiri hasil produksinya ke pasar di kota-kota besar. Hal ini disebabkan adanya keterbatasan yang dimiliki oleh petani Di daerah penelitian biasanya petani menjual kentang kepedagang pengumpul, kemudian pedagang pengumpul menjual langsung ke pedagang pengecer dan ada juga tidak melalui pedagang pegumpul melainkan petani langsung menjual ke pedagang pengecer yang ada di desa tersebut.

\section{Saluran (I)}

Petani $\rightarrow$ Pedagang Besar $\rightarrow$ Pedagang Pengecer $\rightarrow$ Konsumen di Medan

Berdasarkan saluran I diketahui bahwa petani menjual produksi kentang kepada pedagang besar yang biasanya datang langsung ke tempat petani dengan volume beli $7.000 \mathrm{~kg}$, dimana pedagang besar harus mengeluarkan biaya transportasi bongkar muat, penyimpanan, retribusi dan penyusutan. Selanjutnya para pedagang besar menjual kentang ke beberapa pedagang pengecer, selanjutnya dari pengecer dibeli konsumen akhir. Pedagang besar pada saluran ini selanjutnya menjual kentang kepada pedagang pengecer di Medan. Pedagang besar mengeluarkan biaya untuk pengangkutan ke Medan, biaya sortasi, biaya pengepakan kentang. Setelah sampai di Medan, kemudian dijual kepada pedagang pengecer yang seterusnya dijual kepada konsumen. Biaya yang dikeluarkan oleh pedagang pengecer meliputi biaya pengangkutan, pembelian kantong plastik dan retribusi pasar. Selanjutnya dari pedagang pengecer disalurkan ke konsumen akhir, dimana konsumen 
membeli sesuai dengan kebutuhannya saja.

\section{Saluran (II)}

Petani $\longrightarrow$ Pedagang Pengecer $\longrightarrow$ Konsumen di Medan

Pada saluran ini petani kentang langsung menjual ke pedagang pengecer yang ada di Pasar Berastagi dengan volume jual sebesar $2.000 \mathrm{~kg}$, pedagang pengecer membawa produksi kentang ke pasar di Medan, setelah sampai di pasar dijual kepada konsumen akhir. Dari keterangan dan skema saluran (2) di atas dapat terlihat bahwa petani langsung menjual ke pedagang pengecer ke pasar. Biaya yang dikeluarkan pedagang pengecer meliputi biaya pengangkutan komoditi kentang sampai ke pasar, tempat, kantong plastik dan retribusi pasar.

\section{Saluran (III)}

Petani $\longrightarrow$ Pedagang Pengumpul $\longrightarrow$ Pedagang Pengecer di Berastagi

Pada saluran ini petani kentang langsung menjual ke pedagang pengumpul yang ada di desa Sempajaya dengan volume jual sebesar $1.000 \mathrm{~kg}$. Selanjutnya, pedagang pengumpul menjual kentang tersebut ke pasar di Berastagi, setelah sampai di pasar dijual kepada pedagang pengecer. Berdasarkan skema saluran (III) pemasaran di atas diketahui bahwa pedagang pengumpul yang biasanya mengumpulkan kentang langsung dari petani. Adapun biaya yang dikeluarkan pedagang pengumpul meliputi biaya pengangkutan, retribusi, kantong plastik, bongkar muat, dan biaya penyusutan.
Tawarniate et al. (2017), melakukan analisis pemasaran kentang dengan jumlah saluran pemasaran yaitu 3. Lembaga pemasaran kentang yang terlibat yaitu petani, pedagang pengumpul kecamatan, pedangang pengumpul desa, pedagang besar luar daerah dan pedangan pengecer. Pada penelitian yang dilakukan Sari et al. (2018), terdapat tiga saluran pemasaran kentang yaitu Petani; Pedagang Besar;Pedagang Kecil ; Konsumen (Saluran Pemasaran I), Petani; Pedang Pengepul; Pedagang Besar;Pedagang Kecil - Konsumen (Saluran Pemasaran II), dan Petani; Pedagang Besar; Pabrik Pengolah Makanan /Konsumen (Saluran Pemasaran III). Sedangkan Menurut Abhar et al., (2018). terdapat 2 saluran pemasaran kentang di Desa Pulau Tengah Kecamatan Jangkat Kabupaten Merangin, yaitu : Saluran I : Petani Kentang, Pedagang Pengumpul, Pedagang Pengecer dan Konsumen dan Saluran II : Petani Kentang, Pedagang Pengumpul dan Konsumen. Dengan nilai margin pemasaran sebesar $\mathrm{Rp}$ $3.608 / \mathrm{kg}$ pada saluran I dan $\mathrm{Rp}$ $2.888 / \mathrm{kg}$ pada saluran II.

\section{SIMPULAN}

Pada penelitian ini dapat disimpulkan secara simultan luas lahan, curahan tenaga kerja dan biaya sarana produksi berpengaruh signifikan terhadap produksi usahatani kentang. Selanjutnya secara parsial biaya sarana produksi berpengaruh signifikan terhadap produksi usahatani kentang, sedangkan luas lahan dan curahan tenaga kerja tidak berpengaruh 
signifikan. Usahatani kentang layak diusahakan di daerah penelitian dengan diperolehnya nilai $\mathrm{R} / \mathrm{C}$ rasio $(2,14)>1$, BEP produksi sebesar $6.082,14 \mathrm{~kg}<$ rata-rata produksi kentang per petani sampel sebesar $7.930 \mathrm{~kg}$, dan BEP harga sebesar Rp $2.583,73 / \mathrm{kg}<$ rata-rata harga jual kentang sebesar Rp 5.500/kg. Terdapat tiga saluran pemasaran kentang di daerah penelitian yaitu : (1) Petani $\rightarrow$ Pedagang Besar $\rightarrow$ Pedagang Pengecer $\rightarrow$ Konsumen di Medan, (2) Petani $\rightarrow$ Pedagang Pengecer $\rightarrow$ Konsumen di Medan dan (3) Petani $\rightarrow$ Pedagang Pengumpul $\rightarrow$ Pedagang Pengecer di Berastagi.

\section{DAFTAR PUSTAKA}

Abhar, E., Isyaturriyadhah, I., \& Fikriman, F. (2018). Analisis Pemasaran Kentang Di Desa Pulau Tengah Kecamatan Jangkat Kabupaten Merangin. JAS (Jurnal Agri Sains), 2(1). https://doi.org/10.36355/jas.v2i1.17 9

Agatha, M. K., \& Wulandari, E. (2018). Analisis Faktor-Faktor yang Mempengaruhi Produksi Kentang di Kelompok Tani Mitra Sawargi Desa Barusari Kecamatan Pasirwangi Kabupaten Garut. Jurnal Ilmiah Mahasiswa Agroinfo Galuh, 4(3), 772778.

https://jurnal.unigal.ac.id/index.php /agroinfogaluh/article/view/1643

Budiwan, D. W., Purba, P., \& Dachban, S. M. B. (2014). Analisis Pendapatan dan Keuntungan Usaha Tani Kentang di Kabupaten Karo. Wahana Inovasi, 3(1), 191-199.

Direktorat Jendral Hortikultura. (2018). Laporan Tahunan Direktorat Jendral Hortikultura.

Dirjen Hortikultura. (2014). Statistik Produksi Hortikultura Tahun 2013 (p. 290).
Fianda, A., Jalil, F., \& Zuriani, Z. (2016). Analisis Faktor-Faktor Yang Mempengaruhi Produksi Kentang Di Kecamatan Timang Gajah Kabupaten Bener Meriah. Agrifo: Jurnal Agribisnis Universitas Malikussaleh, 1(1), 42. https://doi.org/10.29103/ag.v1i1.10 80

Khazanani, A. (2011). Analisis Efisiensi Penggunaan Faktor-faktor Produksi Usahatani Cabai Kabupaten Temanggung (Studi Kasus di Desa Gondosuli Kecamatan Bulu Kabupaten Temanggung). Skripsi Universitas Diponegoro, 62.

Kiloes, A. M., Sayekti, A. L., \& Anwarudin Syah, M. J. (2016). Evaluasi Daya Saing Komoditas Kentang di Sentra Produksi Pangalengan Kabupaten Bandung. Jurnal Hortikultura, 25(1), 88. https://doi.org/10.21082/jhort.v25n 1.2015.p88-96

Kusuma, N. P., Edison, ., \& Ernawati, . (2015). Analisis Pendapatan Usahatani Kentang Di Kecamatan Jangkat Kabupaten Merangin. Jurnal Ilmiah Sosio-Ekonomika Bisnis, 18(1), 93-99.

https://doi.org/10.22437/jiseb.v18i 1.2820

Minsyah, N. I. (2009). Potensi dan Strategi Pengembangan Agribisnis Kentang di Kabupaten Kerinci Provinsi Jambi.

Pratiwi, L. F. L., \& Hardyastuti, S. (2018). Analisis Faktor-Faktor Yang Mempengaruhi Pendapatan Usahatani Kentang Pada Lahan Marginal Di Kecamatan Kejajar Kabupaten Wonosobo. Berkala Ilmiah AGRIDEVINA, 7(1), 14-26. https://doi.org/10.33005/adv.v7i1.1 127

Rahmah, S. A., \& Wulandari, E. (2021). Analisis pendapatan petani kentang dan faktor-faktor yang berhubungan dengna pendapatan kentang di Kecamatan Pangalengan, kabupaten Bandung. Jurnal Ekonomi Pertanian Dan Agribisnis, 5, 1-15. 
Ri Esso, A. S., \& Ernawati. (2018). ESTIMASI PRODUKSI USAHATANI KENTANG (Estimation of Potato Farm Production). JEKPEND: Jurnal Ekonomi Dan Pendidikan, 1(1), 73. https://doi.org/10.26858/jekpend.v $1 \mathrm{i} 1.5062$

Riadi, E. (2015). Prinsip Dasar EkoMetode Statistik Parametrik dan Nonparametrik. Pustaka Mandiri.

Rizkiyah, N., Syafrial, \& Hanani, N. (2014). Faktor-faktor yang mepengaruhi efisiensi teknis usahatani kentang (Solanum Tuberosum L) dengan pendekatan Stochastic ProductionFfrontier. Habitat, XXV(1), 5-8.

Rulianto, F., Utami, D. P., Hasanah, U., Studi, P., Fakultas, A., Universitas, P., \& Purworejo, M. (2019). SURYA AGRITAMA Volume 8 Nomor 1 Maret 2019 Faktor- Faktor ... - Fajar Rulianto Faktor- Faktor ... - Fajar Rulianto. 8, 66-80.

Sa'diyah, A. A., \& Muljawan, R. eko. (2011). Kajian ekonomi usahatani kentang di Kecamatan Sukapura Kabupaten Probolinggo. Buana Sains, 11(1), 71-
76.

Saida, S., Sabiham, S., Widiatmaka, W., \& Sutjahjo, S. H. (2011). Analisis Keberlanjutan Usahatani Hortikultura Sayuran Pada Lahan Berlereng Di Hulu Das Jeneberang, Sulawesi Selatan. Jurnal Matematika Sains Dan Teknologi, 12(2), 101-112. https://doi.org/10.33830/jmst.v12i2 .550 .2011

Sari, D. W., Suswadi, \& Handayani. (2018). Analisi pemasaran kentang manis (Ipomeae battas L) pada Kelompok Tani Makmur di Desa Puntukrejo Kecamatan Ngargoyoso Kabupaten Karanganyar. AGRINECA, 274-282. http://ejournal.utp.ac.id/index.php/ AFP/article/view/646

Sartika, Sitepu, H. R., \& Bangun, P. (2013). Analisis Faktor-Faktor Yang Produksi Kentang. Saintia Matematika, 1(5), 445-457.

Tawarniate, M. van, Susanti, E., \& Sofyan. (2017). Analisis pemasaran kentang di Kecamtan Bukit Kabupaten Bener Meriah. Jurnal Ilmiah Mahasiswa Pertanian Unsyiah, 2(1), 31-38. 